Bartosz Rakoczy ${ }^{l}$

\title{
Aksojologiczne podstawy ustawy o rodzinnych ogrodach działkowych
}

Ustawa z dnia 8 lipca 2005 r. o rodzinnych ogrodach działkowych ${ }^{2}$ nie jest przedmiotem szerszego zainteresowania jurysprudencji, a nawet judykatury ${ }^{3}$. Ustawa ta bez wątpienia wymaga szerszej analizy w piśmiennictwie z kilku względów. Po pierwsze, reguluje ona materię o znacznej doniosłości społecznej, która wynika z funkcji, jaką pełnią rodzinne ogrody działkowe. Ustawa ta zawiera też interesujące rozwiązania legislacyjne, przede wszystkim z punktu widzenia konstrukcji rzeczowoprawnej. Interesującą jest również sama konstrukcja ustawy o rodzinnych ogrodach działkowych. Wprawdzie ustawa ta nie zawiera formalnie preambuły, ale jej początkowe przepisy są tak skonstruowane, jakby miały pełnić rolę preambuły. W tych właśnie przepisach zawarte są aksjologiczne podstawy całej ustawy o rodzinnych ogrodach działkowych.

W piśmiennictwie wyróżnia się preambułę $\mathrm{w}$ znaczeniu formalnym i w znaczeniu materialnym ${ }^{4}$. Preambuła w znaczeniu formalnym oznacza „część aktu normatywnego, która znajduje się po tytule, ale przed częścią artykułowaną”. „Preambuła w znaczeniu materialnym występuje w postaci numerowanych artykułów czy paragrafów o treści, która mogłaby się równie dobrze znaleźć w preambule"•. W przypadku ustawy o rodzinnych ogrodach działkowych mamy do czynienia z preambułą w znaczeniu materialnym, gdyż występuje tu tekst artykułowany, ale jednocześnie o treści, która bez wątpienia mogłaby być uznana za preambułę w znaczeniu formalnym.

Uwzględniając powyższe okoliczności, uzasadnione jest nie tylko podjęcie rozważań dotyczących samej ustawy o ogrodach działkowych z uwagi na brak ja-

Uniwersytet Mikołaja Kopernika w Toruniu.

Dz.U. Nr 169 poz. 1419 ze zm., dalej jako ustawa o rodzinnych ogrodach działkowych.

Problematyka rodzinnych ogrodów działkowych nie doczekała się nawet analizy w opracowaniu P. Wancke, Nieruchomości. Leksykon pojęć i definicji, Warszawa 2007.

4 M.E. Stefaniuk, Preambuła aktu normatywnego $w$ doktrynie oraz w procesie stanowienia prawa $w$ latach 19892007, Lublin 2009, s. 53.

5 Ibidem

6 Ibidem 
kiejkolwiek literatury, ale także uzasadnione jest podjęcie rozważań dotyczących aksjologii tej ustawy. Przedmiotem tego opracowania będzie zatem analiza aksjologicznych podstaw aktu prawnego, a następnie ich ocena i zgłoszenie ewentualnych uwag de lege ferenda.

Rozważania dotyczące aksjologii systemu prawnego są niezwykle istotne i to nie tylko z punktu widzenia teorii prawa, ale także z punktu widzenia dogmatycznych nauk szczegółowych. Jak trafnie stwierdza A. Kość, „Każdy, kto prawo stanowi i prawo stosuje, musi kierować się wartościami" 7 . Zaobserwować można bowiem zjawisko, polegające na tym, że wykładnia językowa coraz częściej prowadzi do niepożądanych wyników i chociaż jej prymat przy ustaleniu treści normy prawnej nie jest kwestionowany, to jednak coraz częściej konieczne jest poszukiwanie innych metod wykładni. W konsekwencji wzrastać musi rola wykładni celowościowej, która w znacznie szerszym zakresie niż wykładnia językowa odnosi się do aksjologicznych podstaw systemu prawnego. Poszukiwania aksjologicznych podstaw systemu prawnego, czy też tylko poszczególnych aktów prawnych zapewnia interpretatorowi normy prawnej bardziej stabilny wynik wykładni i w dalszej konsekwencji bardziej stabilny sposób rozumienia normy prawnej. „Jeśli bowiem zakładamy, że działalność prawodawcza jest działalnością celową, to jest, że służy ona realizacji określonych celów, to w oczywisty sposób cele te musi uwzględniać także interpretator"».

Jednak wykładnia celowościowa, odwołująca się do aksjologii, wymaga od interpretatora normy prawnej podjęcia wysiłku zmierzającego do ustalenia, a następnie opisania, jakie to wartości leżą u podstaw przyjętych rozwiązań. Jednak wysiłek ten daje zadowalający efekt, gdyż pozwala ustalić stabilny fundament aktu prawnego i pozwala spojrzeć na rozwiązania szczegółowe w szerszej aksjologicznej perspektywie.

Ustawa o rodzinnych ogrodach działkowych jest dobrym przykładem aktu prawnego, którego aksjologia jest szczególnie istotna i ważna dla prawidłowego ustalenia treści norm prawnych. Ustawa ta jest również dobrym przykładem na znaczenie przebudowy aksjologii przyjętych rozwiązań. Kwestie ogrodów działkowych były bowiem także przedmiotem regulacji w Polskiej Rzeczypospolitej Ludowej. W ostatnim okresie istnienia Polskiej Rzeczypospolitej Ludowej zagadnienia te regulowała ustawa z dnia 6 maja 1981 r. o pracowniczych ogrodach działkowych ${ }^{9}$, która w niewielkim zakresie obowiązuje zresztą do dziś.

7 A. Kość, Relacje prawa i wartości w społeczeństwie otwartym, (w:) I. Bogucka, Z. Tobor (red.), Prawo a wartości. Księga jubileuszowa Profesora Józefa Nowackiego, Kraków 2003, s. 142.

8 L. Morawski, Wstęp do prawoznawstwa, wyd. 12, Toruń 2009, s. 150.

9 Dz.U. z 1996 r. Nr 85, poz. 390 ze zm. 
Co jednak istotne, niektóre podstawy aksjologiczne ustawy o pracowniczych ogrodach działkowych są również urzeczywistniane w obecnie obowiązującej ustawie o rodzinnych ogrodach działkowych. Należy jednak zauważyć bardzo istotną aksjologiczną różnicę, jaką jest odmienne ukształtowanie zakresu podmiotowego. O ile bowiem w przypadku ustawy o pracowniczych ogrodach działkowych prawodawca zwracał uwagę na potrzeby pracownika, o tyle w ustawie o rodzinnych ogrodach działkowych akcentuje się rodzinny charakter takich ogrodów. W przypadku ustawy o pracowniczych ogrodach działkowych miały one zaspokajać potrzebę wypoczynku i rekreacji pracownika i w tym kontekście były ideologicznie powiązane z całą aksjologią tamtego systemu prawnego. Ustawa o rodzinnych ogrodach działkowych wprawdzie również akcentuje wartość wypoczynku i rekreacji, ale czyni to w oderwaniu od stosunku pracy i osoby pracownika. Ma zatem znacznie szerszy podmiotowo fundament aksjologiczny.

Ustawodawca definiuje pojęcie rodzinnego ogrodu działkowego w art. 6 ustawy o rodzinnych ogrodach działkowych, który stanowi iż: „Rodzinnym ogrodem działkowym w rozumieniu ustawy jest wydzielony obszar gruntu będący we władaniu Polskiego Związku Działkowców, podzielony na tereny ogólne i działki oraz wyposażony w infrastrukturę niezbędną do jego prawidłowego funkcjonowania."

Definicja legalna wiąże rodzinne ogrody działkowe przede wszystkim z pojęciem gruntu. Specyficzną cechą tego gruntu jest to, że znajduje się on we władaniu Polskiego Związku Działkowców i powinien być podzielony na część przeznaczoną do ogólnego korzystania oraz na część przeznaczoną do wyłącznego korzystania przez poszczególnych członków tego związku.

Istotnym elementem rodzinnego ogrodu działkowego jest wyposażenie tego ogrodu w infrastrukturę niezbędną do jego prawidłowego funkcjonowania. Istnienie owej infrastruktury zmienia znaczenie elementu gruntu jako istotnej przesłanki definicji rodzinnego ogrodu działkowego. Ustawodawca bowiem w art. 4 wskazuje wyraźnie, że rodzinne ogrody działkowe są urządzeniami użyteczności publicznej. Zatem rodzinny ogród działkowy nie może być uznany za grunt o szczególnym przeznaczeniu, choć bez wątpienia istnienie tego gruntu jest warunkiem sine qua non rodzinnego ogrodu działkowego.

Natomiast odwołanie się przez ustawodawcę do kwestii infrastruktury powoduje przesunięcie akcentu gruntu na urządzenie użyteczności publicznej. Ustawodawca polski, choć używa pojęcia „urządzenie użyteczności publicznej” w szerokim zakresie, to jednak nie definiuje, co to pojęcie oznacza. W piśmiennictwie z zakresu prawa gospodarki komunalnej słusznie zauważono, że ,chodzi zatem o takie przedmioty materialne [...], które służą do bieżącego i nieprzerwanego (ciągłego) zaspokajania szczególnego rodzaju potrzeb ludności (potrzeb o charakterze użyteczności publicznej), a mianowicie potrzeb elementarnych, absolutnych, podstawowych 
i występujących powszechnie, przy czym zaspokajanie tych potrzeb ma następować poprzez dostarczanie (świadczenie) osobom je artykułującym usług powszechnie dostępnych, czyli takich, które albo mają charakter niewykluczalny (i są w sensie ekonomicznym zaliczane do kategorii tzw. dóbr publicznych), albo też muszą być obligatoryjnie udostępniane wszystkim podmiotom żądającym ich świadczenia z uwagi na brzmienie stosownych przepisów prawa (przewidujących taki obowiązek). [...] Do tego rodzaju obiektów i urządzeń użyteczności publicznej należą chociażby takie służące do wykonywania zadań o charakterze użyteczności publicznej przedmioty, jak obiekty kultury, obiekty ochrony zdrowia, tereny rekreacyjne i wypoczynkowe, parki czy też targowiska (warto byłoby także przytoczyć tezę wyroku jednego z wojewódzkich sądów administracyjnych, w myśl której o obiekcie lub urządzeniu użyteczności publicznej można mówić tylko w przypadku, gdy został on faktycznie wyodrębniony z mienia gminnego i stanowi pewną zorganizowaną całość"10.

Aksjologia ustawy o rodzinnych ogrodach działkowych wyrażona jest przede wszystkim w art. 1-8.

Zgodnie $\mathrm{z}$ art. 1 ustawy o rodzinnych ogrodach działkowych: „Istnienie i rozwój rodzinnych ogrodów działkowych jest przejawem świadomej polityki Państwa w zaspokajaniu potrzeb społeczeństwa”.

$\mathrm{Z}$ art. 1 wynika, że podstawowym celem istnienia rodzinnych ogrodów działkowych jest zaspokajanie potrzeb społeczeństwa. Ustawodawca wprawdzie nie wskazuje, jakie to potrzeby mają być zaspokajane poprzez istnienie rodzinnych ogrodów działkowych. Niemniej jednak można przyjąć, że chodzi o potrzebę wypoczynku, rekreacji, budowania więzi międzyludzkich, zaspokajania potrzeb obcowania z przyrodą, podejmowania pracy fizycznej w celach wypoczynkowych itp.

Można również przyjąć, że w przypadku rodzinnych ogrodów działkowych istotne znaczenie ma zaspokajanie potrzeby poczucia prawa do wyłącznego dysponowania częścią gruntu, szczególnie w przypadku takich osób, którym nie przysługuje ani prawo własności nieruchomości lokalowej, ani własnościowe spółdzielcze prawo do lokalu, ani wreszcie prawo własności nieruchomości gruntowej. Chodzi tutaj o poczucie wyłączności, ekskluzywności i zaspokajanie potrzeb „posiadania kawałka ziemi”. Trafnie podkreśla A. Jamróz, iż państwo realizuje nie tylko interes ogólnospołeczny, ale także interesy określonych grup społecznych - klas czy warstw ${ }^{11}$. Przykładem takiego ujęcia funkcji państwa jest wlaśnie istnienie rodzinnych ogrodów działkowych.

10 M. Szydło, Ustawa o gospodarce komunalnej. Komentarz, Warszawa 2008, s. 314.

11 A. Jamróz, Wprowadzenie do prawoznawstwa, Warszawa 2008, s. 35. 
$\mathrm{Z}$ art. 1 ustawy o rodzinnych ogrodach działkowych wynika również to, że mają być one elementem świadomej polityki państwa, zmierzającej do zaspokojenia potrzeb społecznych. Owa świadomość państwa, czemu mają służyć rodzinne ogrody działkowe, jest bez wątpienia wartością samą w sobie. Pozwala bowiem na sformułowanie tezy, że państwo najpierw identyfikowało te potrzeby, względnie je nadal identyfikuje i wychodzi tym potrzebom naprzeciw, sprzyjając w tworzeniu rodzinnych ogrodów działkowych. Daje to pewność pewnej stabilności aksjologicznej i dalszych działań państwa, zmierzających do urzeczywistniania tych potrzeb społeczeństwa.

Kolejnym przepisem o dużym znaczeniu dla analizowanego zagadnienia jest art. 2 ustawy o rodzinnych ogrodach działkowych. Przepis ten stanowi, iż: „,Rodzinne ogrody działkowe, jako stały, niezbędny i ważny element infrastruktury miast i gmin, powinny być uwzględniane w procesie ich rozwoju."

Przepis ten wiąże się ściśle z problematyką zagospodarowania przestrzennego, a także problematyką planowania przestrzennego. Poprzez ten przepis ustawodawca w procesie planistycznym nakazuje uwzględniać istnienie rodzinnych ogrodów działkowych, traktując je jako stały i naturalny element ładu przestrzennego. Obecnie w praktyce można zauważyć, że dynamiczny rozwój infrastruktury miast stanowi zagrożenie dla istnienia rodzinnych ogrodów działkowych, gdyż nierzadko ogrody te znajdują się w atrakcyjnych częściach miasta, co powoduje ich likwidację z uwagi na to, że nieruchomości te są wykorzystywane właśnie dla osiągania celów inwestycyjnych.

Występuje tutaj konflikt wartości, który dotyczy rodzinnych ogrodów działkowych z jednej strony, a potrzeb inwestycyjnych i rozwojowych infrastruktury miejskiej z drugiej. Konflikt ten powinien być rozstrzygany i rozwiązywany przede wszystkim z uwzględnieniem koncepcji zrównoważonego rozwoju. Konflikt ten jest o tyle interesujący, że występują w nim praktycznie wszystkie elementy, które w koncepcji zrównoważonego rozwoju się urzeczywistnia. W grę wchodzą bowiem potrzeby gospodarcze i ekonomiczne $\mathrm{z}$ jednej strony, a potrzeby społeczne kulturowe, socjalne, a nawet egzystencjalne, $\mathrm{z}$ drugiej strony. Nie bez znaczenia jest również to, że rodzinne ogrody działkowe są także elementem ochrony środowiska, która jako wartość również jest chroniona w ramach zrównoważonego rozwoju ${ }^{12}$.

Problematyką zrównoważonego rozwoju zajmował się szerzej Trybunał Konstytucyjny w orzeczeniu z dnia 6 czerwca 2006 r. w sprawie K 23/05, który w uzasadnieniu swojego wyroku stwierdził, że: „Władze publiczne są bowiem przede wszystkim zobowiązane do <<prowadzenia polityki zapewniającej bezpieczeństwo ekologiczne współczesnemu i przyszłym pokoleniom >> (art. 74 ust. 1). Sformuło- 
wanie to ma charakter typowy dla określenia zadań (zasad polityki) państwa, nie rodzi natomiast bezpośrednio jakichkolwiek praw podmiotowych po stronie jednostki. Pojęcie <<bezpieczeństwo ekologiczne>> należy rozumieć jako uzyskanie takiego stanu środowiska, który pozwala na bezpieczne przebywanie w tym środowisku i umożliwia korzystanie z tego środowiska w sposób zapewniający rozwój człowieka. Ochrona środowiska jest jednym z elementów „bezpieczeństwa ekologicznego", ale zadania władz publicznych są szersze - obejmują też działania poprawiające aktualny stan środowiska i programujące jego dalszy rozwój. Podstawową metodą uzyskania tego celu jest - nakazane przez art. 5 Konstytucji - kierowanie się zasadą zrównoważonego rozwoju, co nawiązuje do ustaleń międzynarodowych, w szczególności konferencji w Rio de Janeiro w 1992 r. (por. J. Boć, (w:) Konstytucje Rzeczypospolitej oraz komentarz do Konstytucji RP z 1997 r., pod red. J. Bocia, Wrocław 1998, s. 24 i nast.). W ramach zasad zrównoważonego rozwoju mieści się nie tylko ochrona przyrody czy kształtowanie ładu przestrzennego, ale także należyta troska o rozwój społeczny i cywilizacyjny, związany z koniecznością budowania stosownej infrastruktury, niezbędnej dla - uwzględniającego cywilizacyjne potrzeby - życia człowieka i poszczególnych wspólnot. Idea zrównoważonego rozwoju zawiera więc w sobie potrzebę uwzględnienia różnych wartości konstytucyjnych i stosownego ich wyważenia. Biorąc pod uwagę powyższe, Trybunał Konstytucyjny orzekł, jak w sentencji."

Istotną wartością chronioną w art. 2 ustawy o rodzinnych ogrodach działkowych jest to, że rodzinne ogrody działkowe uznane zostały przez ustawodawcę za stały i niezbędny element rozwoju. Wobec konfliktu, na który wskazywano wyżej, jest to bardzo istotna okoliczność, gdyż po pierwsze rodzinne ogrody działkowe zostały uznane za niezbędny element rozwoju, a po drugie, zostały uznane za stały element rozwoju. Likwidacja zatem rodzinnych ogrodów działkowych w atrakcyjnych częściach miast musi skończyć się tym, że takowe rodzinne ogrody działkowe zostaną odtworzone lub założone w innym miejscu. Niedopuszczalna jest więc redukcja rodzinnych ogrodów działkowych, zmierzająca do ich eliminacji. Dopuszczalna jest co najwyżej zmiana lokalizacji.

Ważnym aksjologicznie elementem jest również element stałości, co oznacza, że istnienie rodzinnych ogrodów działkowych powinno być uwzględnione w szerokiej perspektywie zarówno współczesnego, jak i przyszłych pokoleń. Tym samym można przyjąć, że rodzinne ogrody działkowe są istotnym elementem także koncepcji zrównoważonego rozwoju.

Idea łączenia rodzinnych ogrodów działkowych z zagadnieniami planowania przestrzennego jest również widoczna $w$ art. 8 ustawy o rodzinnych ogrodach działkowych, z którego wynika iż: „Istnienie i rozwój rodzinnych ogrodów działkowych powinny uwzględniać miejscowe plany zagospodarowania przestrzennego." 
Przepis ten jest dobrym przykładem, iż problematyka planowania przestrzennego nie ogranicza się tylko do ustawy z 27 marca z 2003 r. o planowaniu i zagospodarowaniu przestrzennym ${ }^{13}$, ale jest rozproszona $w$ różnych aktach prawnych. Znaczenie ma również to, że art. 8 ustawy o rodzinnych ogrodach działkowych nakłada na gminę obowiązek uwzględniania w miejscowych planach zagospodarowania przestrzennego istnienia rodzinnych ogrodów działkowych. Tym samym dochodzi do ograniczenia planistycznego władztwa gminy. Wymóg ten jednak jest uzasadniony z uwagi na to, że obecnie samorząd terytorialny, dynamicznie się rozwijający, chętniej przeznacza nieruchomości na cele inwestycyjne niż pod rodzinne ogrody działkowe.

Podstaw aksjologicznych ustawy o rodzinnych ogrodach działkowych należy też upatrywać w art. 3, który stanowi, iż: , Spełniając pozytywną rolę w urbanistyce i ekosystemie miast i gmin, rodzinne ogrody działkowe stanowią tereny zielone w rozumieniu innych ustaw, których funkcja polega w szczególności na przywracaniu społeczności i przyrodzie terenów zdegradowanych, ochronie środowiska przyrodniczego, kształtowaniu zdrowego otoczenia człowieka, pozytywnym wpływie na warunki ekologiczne w miastach, ochronie składników przyrody oraz poprawie warunków bytowych społeczności miejskich.”

Przepis ten wiąże się ściśle z art. 5 ustawy o rodzinnych ogrodach działkowych: „Rodzinne ogrody działkowe jako tereny zielone podlegają ochronie przewidzianej w przepisach o ochronie gruntów rolnych i leśnych, a także w przepisach dotyczących ochrony przyrody i ochrony środowiska."

Najogólniej rzecz ujmując, można stwierdzić, że art. 3 i 5 dotyczą wartości, jaką jest ochrona środowiska. Przy tym prawodawca ujmuje ową przesłankę w różnych kontekstach. Raz bowiem odwołuje się do pojęcia „ochrona środowiska” wprost, niekiedy używa pojęcia ,tereny zielone i grunty rolne” z tym zastrzeżeniem, że tereny zielone są ściśle związane z ochroną przyrody. Zarówno art. 3 jak i 5 są bogate w treść normatywną. Już na wstępie art. 3 ustawy o pracowniczych ogrodach działkowych prawodawca zakłada a priori, że rodzinne ogrody działkowe spełniają pozytywną rolę w urbanistyce i ekosystemie miast i gmin. Ustawodawca zastosował tutaj element oceny, choć w praktyce nie miał żadnej możliwości weryfikowania, czy rzeczywiście rodzinne ogrody działkowe spełniają pozytywną rolę w urbanistyce i ekosystemie miast i gmin. Owa pozytywna rola nie jest bowiem możliwa do sprawdzenia na etapie tworzenia rodzinnego ogrodu działkowego. Zatem prawodawca musi zakładać, iż samo utworzenie rodzinnego ogrodu działkowego już jest wystarczające do przyjęcia, że istnieje pozytywny wpływ rodzinnego ogrodu działkowego na środowisko. 
$\mathrm{Z}$ omawianego punktu widzenia kluczowe wydaje się być zakwalifikowanie rodzinnych ogrodów działkowych do kategorii tereny zielone. W tego typu zabiegu legislacyjnym można upatrywać niekonsekwencji prawodawcy co do definiowania pojęcia „rodzinny ogród działkowy”. Wyżej już wskazano, że rodzinny ogród działkowy jest wydzielonym obszarem gruntu. Ustawodawca określił również, że rodzinny ogród działkowy jest urządzeniem użyteczności publicznej. Wreszcie w art. 3 i 5 wskazuje on, że rodzinny ogród działkowy jest terenem zielonym, o ile dało się połączyć ze sobą definicję, iż rodzinny ogród działkowy jest wydzieloną częścią gruntu z definicją, że jest to urządzenie użyteczności publicznej, to połączenie tych dwóch definicji, z definicją rodzinnego ogrodu działkowego pojmowanego jako teren zielony, jest już niemożliwe. W sytuacji, gdy ustawodawca uznaje rodziny ogród działkowy za teren zielony, abstrahuje on tym samym całkowicie od kwestii nieruchomościowych i praw rzeczowych.

Ustawodawca pozostaje również niekonsekwentny w ustaleniu charakteru prawnego rodzinnego ogrodu działkowego, jeśli najpierw stwierdza, że jest to urządzenie użyteczności publicznej, a następnie uznaje rodzinne ogrody działkowe za tereny zielone. Inny jest bowiem charakter prawny urządzeń użyteczności publicznej, a inny terenów zielonych. Wydaje się jednak, że rodzinne ogrody działkowe są bardziej zbliżone konstrukcyjnie do terenów zielonych niż do urządzeń użyteczności publicznej. W przypadku urządzeń użyteczności publicznej eksponowana jest bardziej powszechna dostępność takich urządzeń, podczas gdy w przypadku terenów zielonych w grę wchodzi funkcja, jaką takie tereny powinny pełnić.

Analiza art. 3 i 5 ustawy o rodzinnych ogrodach działkowych prowadzi do wniosku, że ustawodawca przede wszystkim akcentuje funkcje, jakie takie ogrody powinny pełnić. Stąd też zakwalifikowanie rodzinnych ogrodów działkowych do terenów zielonych jest bliższe ich istocie niż uznanie, że są to urządzenia użyteczności publicznej.

Podejście ustawodawcy do rodzinnych ogrodów działkowych jako terenów zielonych jest także zróżnicowane. W art. 3 wskazuje on bowiem, że rodzinne ogrody działkowe są terenami zielonymi w rozumieniu innych ustaw. Ustawodawca bez wątpienia odwołuje się tutaj do ustawy z dnia 16 kwietnia 2004 roku o ochronie przyrody. ${ }^{14}$ Ustawodawca definiuje pojecie ,tereny zieleni” w art. 5 pkt. 21 ustawy o ochronie przyrody. Przepis ten stanowi iż terenami zieleni są: „Tereny wraz $\mathrm{z}$ infrastrukturą techniczną i budynkami funkcjonalnie $\mathrm{z}$ nimi związanymi, pokryte roślinnością, znajdujące się w granicach wsi o zwartej zabudowie lub miast, pełniące funkcje estetyczne, rekreacyjne, zdrowotne lub osłonowe, a w szczególności parki, zieleńce, promenady, bulwary, ogrody botaniczne, zoologiczne, jordanowskie i zabytkowe oraz cmentarze, a także zieleń towarzyszącą ulicom, placom, zabytko- 
wym fortyfikacjom, budynkom, składowiskom, lotniskom oraz obiektom kolejowym i przemysłowym"15.

Zwrócić jednak należy uwagę, że ustawa o ochronie przyrody posługuje się pojęciem „tereny zieleni”, podczas gdy w ustawie o rodzinnych ogrodach działkowych ustawodawca używa pojęcia ,tereny zielone”. W mojej ocenie nie jest to jednak różnica na tyle istotna, aby nie móc przyjąć, że tereny zielone z ustawy o rodzinnych terenach działkowych to nic innego jak tereny zieleni z ustawy o ochronie przyrody.

Zwrócić jednak należy uwagę że prawodawca odwołuje się do pojęcia „tereny zielone" także w art. 5, wskazując, że rodzinne ogrody działkowe są chronione wprawdzie jako tereny zielone, ale nie według ustawy o ochronie przyrody, a według ustawy z dnia 3 lutego 1995 roku, o ochronie gruntów rolnych i leśnych. Bardziej wnikliwa analiza relacji pomiędzy tymi przepisami, które definiują rodzinne ogrody działkowe, wykraczałaby poza ramy tego opracowania, którego celem jest przecież analiza podstaw aksjologicznych samej ustawy. Na potrzeby dalszych rozważań wystarczy stwierdzenie, że rodzinne ogrody działkowe są terenami zielonymi. Jest to dowodem na to, że jedną z wartości chronionych w ustawie o rodzinnych ogrodach działkowych jest ochrona środowiska, w tym ochrona przyrody.

$\mathrm{W}$ art. 3 ustawodawca ponadto wskazuje, że rodzinne ogrody działkowe, jako tereny zielone, mają do spełnienia określone funkcje, wymienione w tym przepisie ustawy o rodzinnych ogrodach działkowych.

Funkcje te, choć szczegółowo opisane w art. 3 ustawy o rodzinnych ogrodach działkowych, da się sprowadzić do wspólnego mianownika i przyjąć, że dotyczą przede wszystkim ochrony środowiska, ale z silnym wątkiem antropocentrycznym. Prawodawca bowiem praktycznie w każdym elemencie wymienionym w art. 3 ustawy o rodzinnych ogrodach działkowych odwołuje się do wartości, jaką jest ochrona środowiska, a w niektórych przypadkach odwołuje się wprost do wątku antropocentrycznego. Zwrócić też należy uwagę, że prawodawca rozkłada akcenty w zakresie ochrony środowiska nierównomiernie. Wyraźnie bowiem widać, że ustawa o rodzinnych ogrodach działkowych w kontekście ochrony środowiska dotyczy przede wszystkim ochrony gruntów i powierzchni ziemi. Wszak prawodawca wskazuje na elementy rekultywacyjne, a ponadto w art. 5 ustawy o rodzinnych ogrodach działkowych odwołuje się do ochrony terenów zielonych według ustawy o ochronie gruntów rolnych i leśnych ${ }^{16}$.

W ramach ochrony środowiska prawodawca polski ujmuje również kreacyjną funkcję rodzinnych ogrodów działkowych, która jest dość silnie eksponowana. Prawodawca dostrzega bowiem, że rodzinne ogrody działkowe mają wpływ na warunrody, Warszawa 2009; K. Gruszecki, Ustawa o ochronie przyrody, wyd. 2, Warszawa 2010. W. Radecki, Ustawa o ochronie gruntów rolnych i leśnych. Komentarz, Warszawa 2009. 
ki ekologiczne w miastach. Ponadto wskazuje, że rodzinne ogrody działkowe przyczyniają się do kształtowania zdrowego otoczenia człowieka. Nie bez znaczenia jest tutaj zapewne okoliczność, iż rodzinne ogrody działkowe wiążą się z uprawami rolnymi. Stąd też za jeden $\mathrm{z}$ istotnych elementów rodzinnych ogrodów działkowych uznać należy ich funkcje produkcyjną w uprawach owocowo-warzywnych. Żywność ta z reguły jest zdrowa i pozbawiona negatywnych oddziaływań (przynajmniej częściowo), co w kontekście dyskusji o żywności modyfikowanej genetycznie jest wartością istotną. ${ }^{17}$

Wyżej już wskazywano, że ochrona środowiska jako wartość chroniona w ustawie o rodzinnych ogrodach działkowych jest ściśle powiązana z wątkiem antropocentrycznym. Skłania to do krótkiej refleksji dotyczącej tego, czy, a jeżeli tak, to w jakim stopniu ochrona życia i zdrowia człowieka jest wartością chronioną także w ramach ochrony środowiska.

Wprawdzie legalna definicja środowiska nie wskazuje wprost na człowieka jako na element przyrodniczy, który podlega ochronie, niemniej jednak istotny jest tutaj element powiązania ochrony środowiska z ochroną życia i zdrowia, który występuje chociażby w art. 68 ust 4 Konstytucji RP. Przepis ten stanowi, iż: „Władze publiczne są obowiązane do zwalczania chorób epidemicznych i zapobiegania negatywnym dla zdrowia skutkom degradacji środowiska". Reasumując, ustawa o rodzinnych ogrodach działkowych jest aktem prawnym odwołującym się do szerokich podstaw aksjologicznych. Jest to również akt prawny o interesującej konstrukcji, w którym ustawodawca zrezygnował wprawdzie z preambuły, ale w którym pierwsze przepisy odwołują się właśnie do szerokich podstaw aksjologicznych.

Bez wątpienia aksjologia ta wiąże się z problematyką planowania i zagospodarowania przestrzennego, którego istotnym elementem zarówno normatywnym, jak i faktycznym są właśnie rodzinne ogrody działkowe. Stanowią one ważny element całego planowania przestrzennego, a przede wszystkim miejscowego planu zagospodarowania przestrzennego. Inną wartością, którą można dostrzec w ustawie o rodzinnych ogrodach działkowych, jest ochrona środowiska z szerokim odwołaniem się do antropocentrycznych elementów. Rodzinne ogrody działkowe mają przede wszystkim służyć ochronie powierzchni ziemi. Mają też być elementem poprawiającym warunki ekologiczne. Ustawodawca wiąże rodzinne ogrody działkowe także z zaspokajaniem potrzeb w zakresie zdrowej żywności, związanej z uprawami owocowo warzywnymi. W tym aspekcie można też dostrzec element ochronny w kontekście żywności i organizmów genetycznie zmodyfikowanych. Wreszcie, co chyba należy uznać za najważniejszą wartość, ustawa o rodzinnych ogrodach działkowych w szerokim kontekście odwołuje się do koncepcji zrównoważonego rozwoju. Od- 
wołanie to jednak jest szerokie, gdyż ustawodawca nie poprzestaje jedynie na rozwiązywaniu konfliktów pomiędzy ochroną środowiska a innymi wartościami, ale uwzględnia także inne wartości, takie chociażby, jak wartości społeczne rodzinnych ogrodów działkowych, wartości ekonomiczne, przestrzenne itp. 


\section{Axiological principles of the family allotment act}

Key words: family allotment, axiology, preamble

The family allotment issue is not often taken into account in literature and that is why it is justified to discuss it. The axiology of the family allotment act seems to be a very interesting issue. This act has no formal preamble but it has got a material one. Articles $1-8$ of the family allotment act serve as a preamble. This act clearly shows an appeal to the protection of planning and developing land as well as to the environment protection. The social usefulness of family allotments and meeting holiday-recreation needs are also protected values. 